\title{
Petrogenesis Batuan Metamorf di Perbukitan Jiwo Barat, Bayat, Klaten, Jawa Tengah
}

\author{
Anis Kurniasih $^{1 *}$, Ikhwannur Adha ${ }^{2}$, Hadi Nugroho ${ }^{1}$, Prakosa Rachwibowo ${ }^{1}$ \\ ${ }^{1}$ Departemen Teknik Geologi UNDIP, J1. Prof. Soedharto Tembalang Semarang \\ ${ }^{2}$ Departemen Teknik Geologi ITB, Jl.Ganesha no. 10 Bandung
}

\begin{abstract}
Abstrak
Singkapan batuan yang ditemukan di Komplek Bayat terdiri dari batuan beku, sedimen, dan metamorf memiliki berumur Pra - Tersier hingga Neogen. Keberadaan ketiga jenis batuan dalam lokasi yang berdekatan dan menunjukkan hubungan kontak, hanya mungkin terjadi akibat aktivitas tektonik yang kompleks. Penelitian ini diutamakan untuk mengetahui karakteristik batuan metamorf di Perbukitan Jiwo Barat, Bayat, yang meliputi karakter di lapangan dan mikroskopis, yang selanjutnya digunakan untuk memperkirakan sejarah tektonik yang terjadi di daerah penelitian. Observasi langsung di lapangan dijalankan untuk mengetahui kondisi geologi, terutama litologi. Analisis petrografi dilakukan untuk mendukung peta geologi.

Berdasarkan hasil analisis diketahui bahwa batuan metamorf di daerah penelitian termasuk ke dalam kelompok metamorf derajat rendah (low grade), diwakili oleh batuan sekis muskovit klorit, sekis klorit, dan filit. Kelompok batuan metamorf ini termasuk ke dalam fasies Greenschist yang ditandai dari kehadiran mineral muskovit, klorit dan kuarsa. Diperkirakan batuan ini telah mengalami retrograde metamorphisme, dibuktikan dengan kehadiran mineral muskovit dan klorit hasil rekristalisasi dari biotit, dan plagioklas. Protolit batuan metamorf di daerah penelitian adalah batuan dengan ciri asal darat seperti batulanau dan batulempung, selain itu batuan beku yang ditemukan sebagian besar berkomposisi menengah hingga basa, dan batuan sedimen menunjukkan lingkungan pengendapan laut dangkal. Himpunan batuan di daerah penelitian diinterpretasikan sebagai kompleks konvergen yang lebih berciri asal kontinen, kemungkinan besar terbentuk akibat tumbukan lempeng Benua Eurasia dengan Mikrokontinen Jawa Timur.
\end{abstract}

Kata kunci: petrogenesis, batuan metamorf, Jiwo Barat, Bayat

\begin{abstract}
The outcrops in Bayat Complex consist of Igneous Rocks, Sedimentary and Metamorphic have age ranging from Pre - Tertiary until Neogen. Hence, the history of geology and tectonic setting of research area remained questionable. This research was primarily aimed to know the characteristic of metamorphic rock in West Jiwo Hill, Bayat. Field observation was conducted in order to collect geological data, especially lithology. The data were analyzed to support the geological map. The result shows that metamorphic rock in research area is classified as metamorphic degree (low grade), marked by muscovite - chlorite schist, chlorite schist, and phyllite. Greenschist facies is determined by the appearance of muscovite, chlorite and quartz minerals. The rock experienced retrograde metamorphism, marked by the occurrence of muscovite and chlorite representing recristalization of biotit, and plagioclase minerals. The protolith of metamorphic rock in research area has continental origin characteristic such as siltstone and claystone. In addition, most of the igneous rock composition is intermediate to felsic, and the sedimentary rock shows an inner shelf sedimentary environment. Thus, it can be interpreted that the outcrop in research area represent convergent complex and continent origin which formed by the effect of collision between Eurasia Continental Plate and Microcontinent of East Java.
\end{abstract}

Keywords: petrogenesis, metamorphic rocks, West Jiwo, Bayat

*) Korespondensi : aniskurniasihgeo@gmail.com 
PENDAHULUAN

Singkapan batuan yang ditemukan di Komplek Bayat terdiri dari jenis batuan beku, sedimen, dan metamorf, yang berumur Pra-Tersier hingga Neogen. Hal ini sering menimbulkan berbagai pertanyaan sehubungan dengan sejarah geologi dan tatanan tektonik daerah tersebut. Keberadaan ketiga jenis batuan dalam satu lokasi yang berdekatan dan menunjukkan hubungan kontak, hanya mungkin terjadi akibat aktivitas tektonik yang kompleks.

Penelitian terhadap batuan Paleogen di Pulau Jawa telah banyak dilakukan, tetapi penelitian terhadap batuan Pra-Tersier yang merupakan batuan dasar dari batuan Paleogen tersebut sangat jarang dilakukan. Hal inilah yang mendasari penelitian ini, sehingga penelitian ini diutamakan untuk mengetahui karakteristik batuan Pra Tersier yang umum diketahui sebagai batuan metamorf. Karakteristik yang dipelajari meliputi kenampakan di lapangan yang berguna untuk mengetahui kontak antar batuan, selain itu perlu dilakukan pengamatan petrografi untuk mengetahui karakteristik batuan secara mikroskopis. Penentuan karakteristik batuan metamorf secara mikroskopis yang meliputi komposisi mineral serta tekstur dan struktur maka dapat diketahui protolit, dan kemudian memperkirakan petrogenesis batuan tersebut. Lokasi penelitian mencakup Perbukitan Jiwo Barat, lokasi penelitian ditunjukkan oleh Gambar 1.

\section{Tujuan Penelitian}

Penelitian ini bertujuan untuk mengetahui kondisi singkapan dan hubungan antara batuan metamorf dengan jenis batuan lain di sekitarnya, mengetahui komposisi mineral, struktur dan tekstur batuan metamorf di daerah penelitian, serta mengetahui fasies metamorfisme dan petrogenesis.

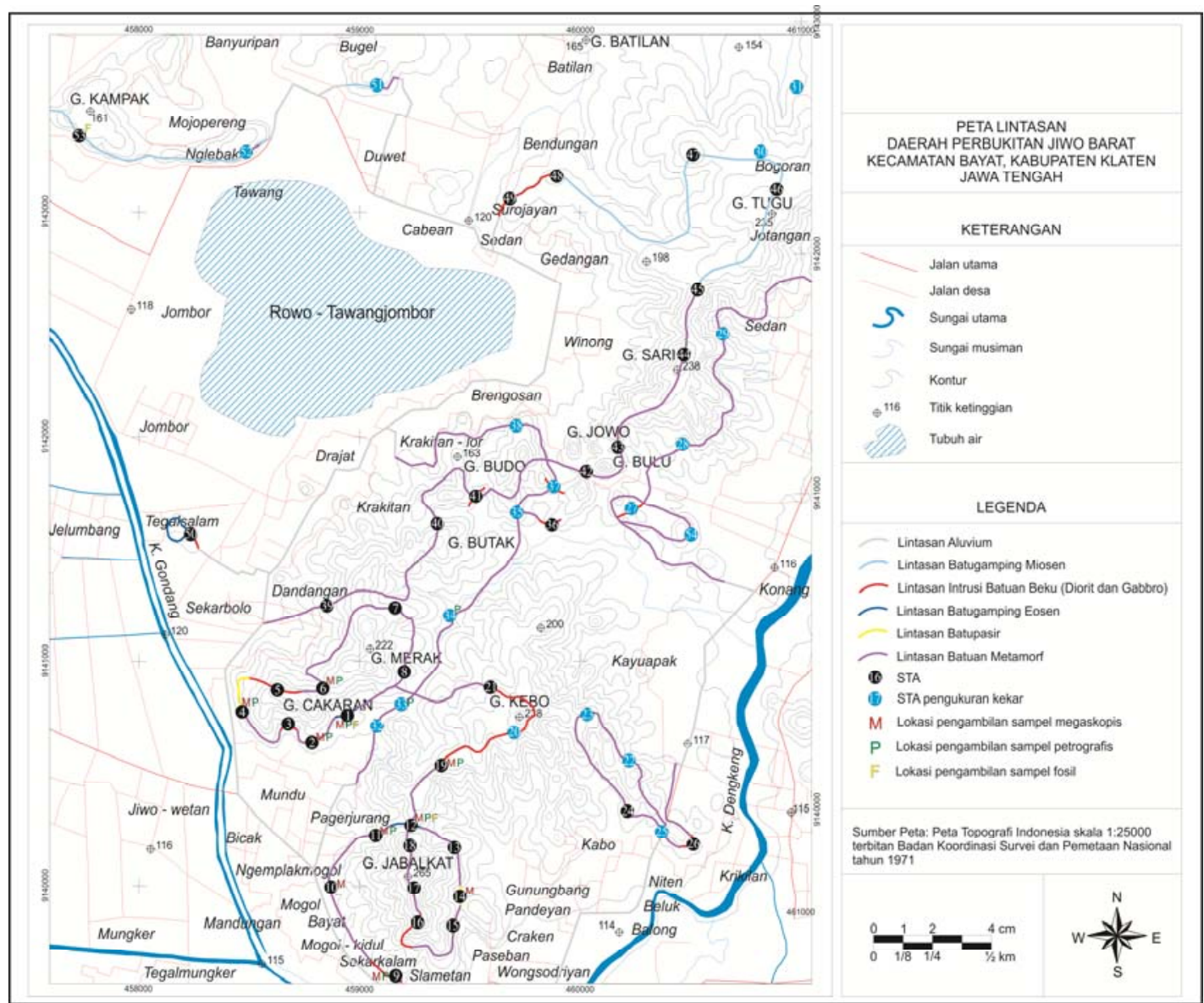

Gambar 1. Peta lokasi dan lintasan penelitian yang meliputi daerah Perbukitan Jiwo Barat, Bayat, Klaten, Jawa Tengah 


\section{METODOLOGI}

Penelitian ini secara umum didasarkan pada evaluasi data lapangan serta analisis petrologi dan petrografi conto batuan yang diperoleh di lapangan. Metode penelitian dilakukan dengan metode survey dan metode deskriptif.

Metode survey dilakukan dengan penyelidikan langsung di lapangan pada daerah penelitian yang bertujuan untuk mengetahui kondisi geologi yang meliputi litologi, struktur geologi, dan geomorfologi. Selain itu, dalam penelitian ini, dilakukan deskripsi dan interpretasi karakteristik batuan metamorf yang ada di daerah penelitian untuk mengetahui proses geologi yang berpengaruh sepanjang sejarah geologi.

\section{HASIL PENELITIAN}

Karakteristik batuan metamorf yang menjadi fokus penelitian ini meliputi karakter di lapangan dan di laboratorium. Karakter di lapangan terutama mengungkapkan tentang hubungan atau kontak antara batuan metamorf dengan batuan di sekitarnya, sedangkan karakter di laboratorium dilakukan melalui pengamatan petrografi dan bertujuan menjelaskan struktur internal, tekstur dan mineralogi batuan untuk memperkirakan petrogenesis dan fasies metamorf.

\section{Kontak Batuan Metamorf dengan Batuan di Sekitarnya}

Pengamatan singkapan batuan metamorf di lapangan sangat berguna dalam menentukan hubungan antara batuan metamorf dengan jenis batuan lain di sekitarnya. Hal ini penting diketahui karena batuan metamorf merupakan batuan dasar dari batuan Tersier yang penting.

Berdasarkan urutan stratigrafi, batuan metamorf adalah batuan yang paling tua, secara tidak selaras di atas batuan metamorf diendapkan seri batuan klastika dan karbonat yang kaya akan kandungan fosil foraminifera besar yang berumur Eosen. Batuan ini tersingkap di beberapa tempat dan tidak menerus sehingga sangat sukar ditentukan kedudukan stratigrafinya. Namun, secara umum kontak antara batuan metamorf dengan batuan di sekitarnya menunjukkan hubungan ketidakselarasan karena adanya perbedaan umur yang sangat jauh.

Di sekitar Tegalsalam ditemukan rombakan sekis yang menyisip pada bidang perlapisan batugamping yang membuktikan bahwa batuan metamorf lebih tua dibanding batugamping ini (Gambar 2). Selain itu singkapan batugamping di G. Jabalkat juga mengandung fragmen filit.

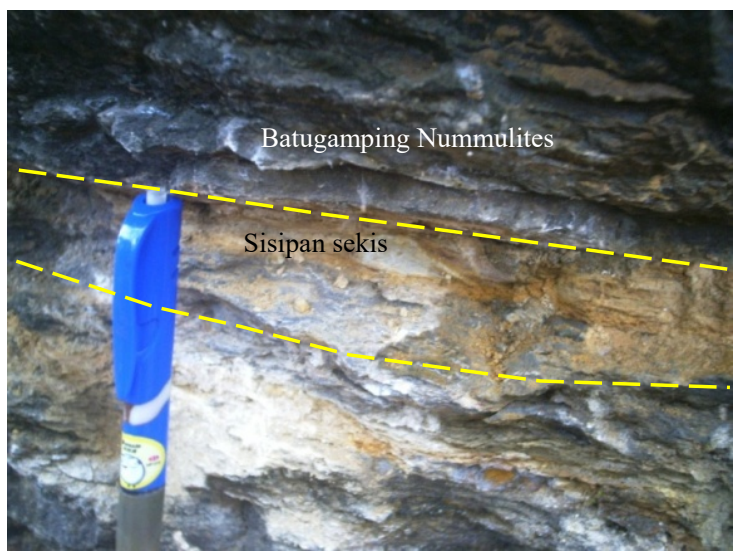

Gambar 2. Rombakan sekis menyisip dalam bidang perlapisan batugamping pada singkapan di Tegalsalam (STA 50).

Secara stratigrafi, satuan batugamping dengan batupasir dikelompokkan menjadi satu dalam Formasi Wungkal Gamping, formasi ini memiliki kedudukan tidak selaras terhadap batuan metamorf.

Batuan metamorf dan Batugamping Eosen, keduanya diterobos oleh batuan beku yang terutama terdiri dari mikrodiorit. Hal ini dibuktikan dari rekristalisasi kalsit pada Batugamping Eosen hampir menjadi marmer yang ditemukan di lereng selatan Jabalkat yang dipengaruhi intrusi. Bukti lain juga ditemukan di daerah Tegalsalam, yakni mineralisasi pirit pada batugamping akibat intrusi. Di lereng G. Jowo dan Bulu ditemukan intrusi diorit yang berderet, hal ini mengindikasikan adanya zona lemah dari sistem patahan yang bekerja di daerah penelitian. Di bagian utara daerah 
penelitian, sekitar G. Tugu tersingkap Batugamping Miosen yang menumpang secara tidak selaras di atas batuan yang lebih tua. Di sekitar G. Kampak, ditemukan kontak antara batuan metamorf dengan batugamping ini, di antara kedua lapisan ditemukan lapisan breksi dengan fragmen dan matriks dari rombakan sekis (Gambar 3).

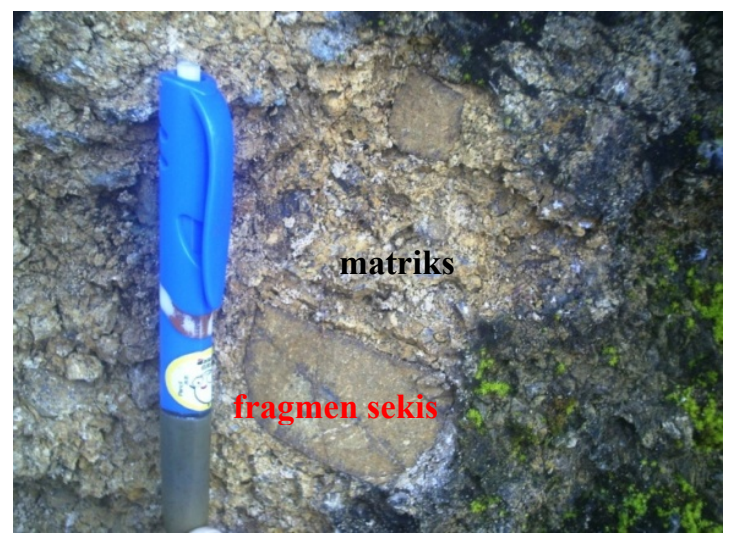

Gambar 3. Fragmen sekis dalam matriks rombakan sekis yang menjadi batas litologi antara sekis dengan Batugamping Miosen yang berupa breksi sesar di lereng selatan G. Kampak (STA 52).

\section{Analisis Petrografi}

Sekis

Pengamatan petrografi dilakukan pada conto batuan yang diambil di sekitar G. Jabalkat (BM II). Pada pengamatan nikol sejajar, batuan ini memperlihatkan struktur foliasi schistosic yang sangat baik. Batuan ini memiliki tekstur faneritik, bentuk individu kristal penyusun batuan didominasi oleh kristal yang berbentuk subhedral, maka tekstur batuan ini tergolong hypidioblastik. Berdasarkan bentuk mineralnya yang sebagian besar prismatik, maka teksturnya nematoblastik.

Komposisi mineral batuan ini didominasi oleh muskovit dan klorit. Kelimpahan mineral muskovit pada batuan adalah $35 \%$, biotit (5\%), klorit 50\%, dan plagioklas $(10 \%)$. Sruktur foliasi ditunjukkan oleh penjajaran mineral muskovit. Mineral klorit dan plagioklas menjadi massa dasar di antara mineral pipih muskovit. Klasifikasi Huang (1962 dalam Yulianto, 1997) menyatakan batuan tersebut bernama Sekis Mika - Klorit, penamaan ini berdasarkan tekstur, struktur dan komposisi mineral batuan (Gambar 4).

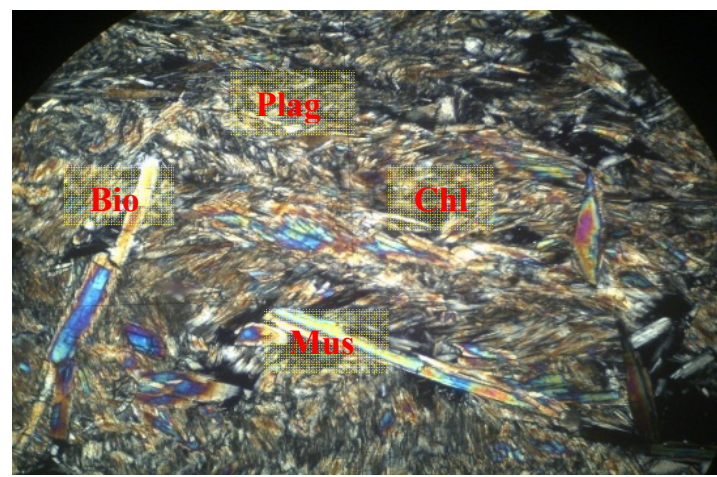

Gambar 4. Struktur schystosic yang menerus dengan komposisi muskovit (Mus), biotit (Bio), klorit (Chl), dan plagioklas (Plag) pada conto batuan BM II.

Filit

Conto batuan filit yang digunakan dalam analisis petrografi diambil di STA 34 di sekitar lereng selatan G. Merak (BM V). Pada pengamatan nikol sejajar, batuan ini menunjukkan penjajaran mineral, tetapi tidak terlihat adanya pemisahan mineral pipih atau memiliki struktur phylitic. Komposisi batuan ini adalah klorit $(85 \%)$ dan kuarsa (15\%). Menurut klasifikasi Huang (1962 dalam Yulianto, 1997), batuan tersebut diklasifikasikan sebagai Filit (Gambar 5).

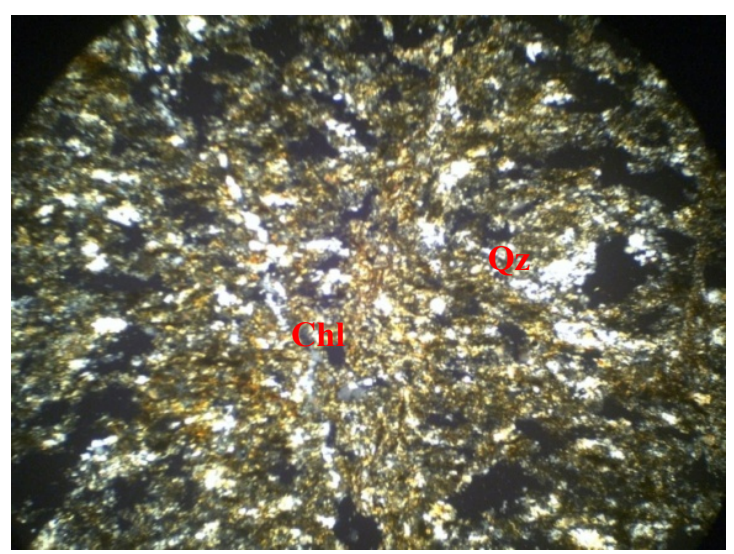

Gambar 5. Struktur foliasi phyllitic dengan komposisi dominan klorit (Chl) dan kuarsa (Qz) pada conto batuan BM V.

\section{Serpentinit}

Serpentinit dijumpai di lereng utara G. Jabalkat dan timur laut G. Cakaran. Lokasi 
ditemukannya serpentinit hampir selalu berdekatan dengan intrusi gabbro, karena serpentinit di daerah penelitian merupakan ubahan dari gabbro. Pada pengamatan nikol sejajar, batuan ini tidak memperlihatkan struktur foliasi tidak dijumpai tekstur batuan asal. Berdasarkan ukuran butirnya, batuan ini memiliki tekstur porfiroafanitik, bentuk individu kristal penyusun batuan didominasi oleh kristal yang berbentuk subhedral, maka tekstur batuan ini tergolong hypidioblastik. Bentuk mineralnya sebagian besar adalah serabut. Komposisi mineral batuan ini adalah serpentin $(42 \%)$, talc $(53 \%)$, dan olivin (5\%). Berdasarkan komposisi mineral yang dominan pada batuan ini adalah serpentin, maka batuan ini bernama Serpentinit (Gambar 6).

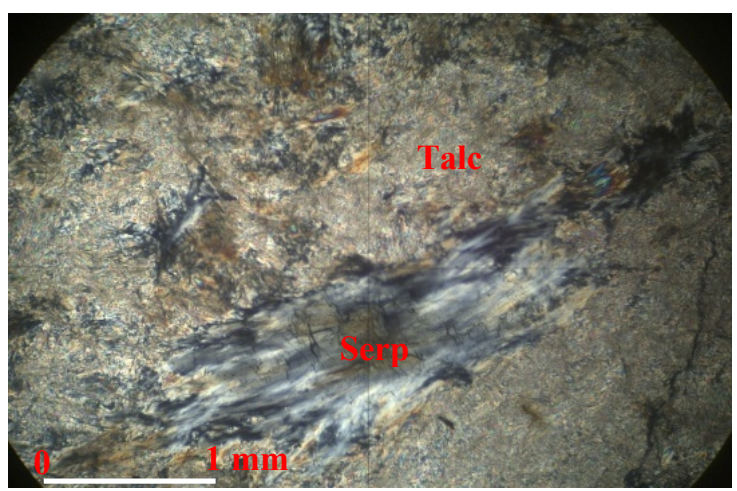

Gambar 6. Komposisi penyusun serpentinit terdiri dari serpentin (Serp) dalam massa dasar talc.

\section{Petrogenesis dan Fasies Metamorf}

Berdasarkan hasil pengamatan petrografi, dapat diketahui bahwa batuan metamorf di daerah penelitian terdiri dari kelompok metamorf derajat rendah (low grade), yang diwakili oleh batuan sekis mika - klorit, sekis klorit, dan filit, hal ini terutama didasarkan pada struktur, tekstur dan mineralogi batuan metamorf. Berdasarkan hal tersebut pula, dapat diinterpretasikan bahwa protolit batuan metamorf di daerah penelitian adalah batuan dengan ciri asal darat seperti batulanau dan batulempung.

Menurut klasifikasi Miyashiro (1973 dalam Mason, 1990), kelompok batuan metamorf ini termasuk ke dalam fasies
Greenschist yang ditandai dari kehadiran mineral muskovit, klorit dan kuarsa.

Menurut model yang disusun oleh Winkler (1986 dalam Mason, 1990), yang merupakan modifikasi dari klasifikasi Miyashiro (1973 dalam Mason, 1990), maka fasies ini terbentuk pada temperatur yang berkisar antara $300-400^{\circ} \mathrm{C}$ dan pada tekanan 0,2 - 0,5 GPa atau sama dengan $2 \times 10^{8}-5 \times 10^{8} \mathrm{~kg} / \mathrm{ms}^{2}$. Secara petrogenesis, metamorfisme derajat rendah (low grade) yang diwakili oleh fasies Greenschist, termasuk ke dalam metamorfisme regional (Barrovian Metamorphism) yang terjadi pada kisaran suhu $150^{\circ}-400^{\circ} \mathrm{C}$ dan tekanan $1-5 \mathrm{KBar}$ atau $1 \times 10^{8}-5 \times 10^{8}$ $\mathrm{kg} / \mathrm{ms}^{2}$ pada kedalaman $3,7-18,5 \mathrm{~km}$.

Protolit batuan metamorf di daerah penelitian adalah batuan dengan ciri asal darat seperti batulanau dan batulempung, dan batuan metamorf yang terbentuk menunjukkan derajat metamorfisme yang rendah. Sementara itu batuan beku yang ditemukan sebagian besar berkomposisi menengah hingga basa, dan batuan sedimen menunjukkan lingkungan pengendapan laut dangkal. Dengan demikian, dapat diinterpretasikan bahwa himpunan batuan di daerah penelitian merupakan kompleks konvergen yang lebih berciri asal kontinen.

Menurut klasifikasi Barker (1990 dalam Patonah, 2007), kandungan mineral pada sekis mika - klorit, mengindikasikan batuan ini telah mengalami retrograde metamorphisme, ditandai dari kehadiran mineral biotit yang terbentuk pada temperatur $425^{\circ} \mathrm{C}-450^{\circ} \mathrm{C}$ dan tekanan 0,4 $-7,7 \mathrm{KBar}$ atau setara dengan $0,4 \times 10^{8}$ $\mathrm{kg} / \mathrm{ms}^{2}-7,7 \times 10^{8} \mathrm{~kg} / \mathrm{ms}^{2}$. Pada fase selanjutnya mineral biotit mengalami rekristalisasi menjadi mineral muskovit dan klorit yang terbentuk pada temperatur $305^{\circ} \mathrm{C}-375^{\circ} \mathrm{C}$ dan tekanan $0,4-5 \mathrm{KBar}$ atau setara dengan $0,4 \times 10^{8} \mathrm{~kg} / \mathrm{ms}^{2}-5 \mathrm{x}$ $10^{8} \mathrm{~kg} / \mathrm{ms}^{2}$. Hal ini berarti telah terjadi penurunan temperatur dan tekanan pada fase metamorfisme yang lebih lanjut. Proses retrogradasi pada metamorfisme dimungkinkan terjadi oleh aktivitas 
pengangkatan atau pengurangan beban dan terjadi sangat lambat. Sehingga dapat diperkirakan batuan metamorf yang terbentuk pada fase sebelumnya telah mengalami proses pengangkatan (uplift) atau pengurangan beban sehingga temperatur dan tekanan menurun secara perlahan.

\section{Sejarah Geologi dan Tatanan Tektonik}

Berdasarkan hasil analisis karakteristik batuan metamorf di lapangan dan di laboratorium, maka dapat diinterpretasikan bahwa batuan metamorf terbentuk oleh proses metamorfisme regional akibat adanya proses orogenesis yang berlangsung lambat pada daerah yang luas. Sementara itu, himpunan batuan di daerah penelitian didominasi oleh batuan metamorf derajat rendah, yang diwakili oleh sekis dan filit, sehingga dapat diinterpretasikan bahwa himpunan batuan di daerah penelitian merupakan kompleks konvergen yang lebih berciri asal kontinen. Interpretasi ini didukung oleh penelitian Prasetyadi (2007), yang mengungkapkan adanya mikrokontinen Jawa Timur yang menumbuk lempeng benua Eurasia pada Kapur Akhir dan mengakibatkan proses subduksi Karangsambung berhenti atau tidak aktif. Diperkirakan daerah penelitian terletak pada mikrokontinen tersebut, yang menandakan batuan metamorf di daerah penelitian terbentuk akibat tumbukan mikrokontinen dengan lempeng benua Eurasia. Selain itu, mikrokontinen tersebut juga memperoleh gaya tektonik yang berarah baratdaya - timurlaut searah dengan arah subduksi Meratus mengakibatkan terbentuknya Sesar Mendatar Tugu dan Sesar Mendatar Kebo.

Proses retrogradasi yang terjadi pada siklus metamorfisme dimungkinkan terjadi oleh aktivitas pengangkatan atau pengurangan beban dan terjadi sangat lambat. Sehingga dapat diperkirakan batuan metamorf yang terbentuk pada fase sebelumnya telah mengalami proses pengangkatan (uplift) atau pengurangan beban sehingga temperatur dan tekanan menurun secara perlahan. Setelah mengalami pengangkatan, batuan ini tersingkap di permukaan dan mengalami proses eksogenik berupa pelapukan dan erosi. Diperkirakan proses ini terjadi pada Eosen Awal.

Pada Eosen Tengah, diperkirakan kembali terjadi penurunan permukaan oleh patahan (subsidence) sehingga daerah ini kembali mengalami genang laut dan terendapkan batuan sedimen Eosen yakni satuan batupasir dan batugamping Nummulites (Formasi Wungkal Gamping).

Setelah itu, pada Eosen Akhir hingga Oligosen Awal mulai terjadi perubahan arah subduksi menjadi berarah utaraselatan yang mengakibatkan pengangkatan kembali dan terbentuk busur gunung api (Old Andesite Formation) pada Oligosen Tengah, diperkirakan pada kala ini banyak terjadi intrusi. Pada Oligosen Tengah hingga Miosen Awal banyak terjadi proses tektonik yang ditandai dengan pengangkatan dan genang laut berturut turut menghasilkan stratigrafi Pegunungan Selatan.

Pada Miosen Tengah, kembali terjadi genang laut sehingga terbentuk batugamping dengan ciri pengendapan laut dangkal. Setelah itu kembali terjadi pengangkatan sehingga batuan yang lebih tua mengalami erosi dan pada zaman Kuarter terbentuk endapan alluvium sebagai satuan litologi yang paling muda dan menumpang secara tidak selaras di atas batuan yang lebih tua.

\section{KESIMPULAN}

Batuan metamorf di daerah penelitian termasuk ke dalam kelompok metamorf derajat rendah (low grade). Kelompok batuan metamorf ini termasuk ke dalam fasies Greenschist.

Secara petrogenesis, metamorfisme derajat rendah (low grade) di daerah penelitian termasuk ke dalam metamorfisme regional (Barrovian Metamorphism) yang terjadi pada kisaran suhu $150^{\circ}-400^{\circ} \mathrm{C}$ dan tekanan $1-5 \mathrm{KBar}$ 
atau $1 \times 10^{8}-5 \times 10^{8} \mathrm{~kg} / \mathrm{ms}^{2}$ pada kedalaman $3,7-18,5 \mathrm{~km}$. Himpunan batuan di daerah penelitian merupakan kompleks konvergen yang cenderung berciri asal kontinen, yaitu bagian dari mikrokontinen Jawa Timur yang menumbuk lempeng benua Eurasia pada Kapur Akhir.

\section{UCAPAN TERIMA KASIH}

Penulis mengucapkan terima kasih sedalam-dalamnya kepada Bapak Tri Winarno dan keluarga serta Eki Wedia yang telah membantu dalam proses pengumpulan data di lapangan. Selain itu, penulis juga mengucapkan terima kasih atas masukan dan kritikan selama proses penulisan kepada Febryan Kusuma dan Vahyu Vanny, serta seluruh pihak yang tak dapat disebutkan satu persatu.

\section{DAFTAR PUSTAKA}

Mason, Roger, 1990. Petrology of the Metamorphic Rocks, Academic Division of Unwin Hyman Ltd, London. Patonah, Aton, 2007. Batuan Metamorf Komplek Melange Luk Ulo, Karangsambung - Banjarnegara, Jawa Tengah, Laporan tidak dipublikasikan, Skripsi, Departemen Teknik Geologi ITB, Bandung.

Prasetyadi, C., 2007. Evolusi Tektonik Paleogen Jawa Bagian Timur, Laporan tidak dipublikasikan, Disertasi, Dept. Teknik Geologi ITB, Bandung.

Yulianto, 1997. Diktat Praktikum Petrologi, Jurusan Teknik Geologi Fakultas Teknik UGM, Yogyakarta. 